\title{
Analisis Faktor-Faktor yang Mempengaruhi Keputusan Mahasiswa dalam Memilih Studi Online Program Sarjana dan Diploma di UPBJJ Ut Jambi
}

\author{
Mahyudin*, Yusrizal \\ Universitas Terbuka Jambi \\ *Correspondence email: mahyudin@ecampus.ut.ac.id, yusrizal@ecampus.ut.ac.id
}

\begin{abstract}
Abstrak. Penelitian ini dilatarbelakangi karena penyelenggaraan studi online telah diminati mahasiswa yang registrasi di UPBJJ UT Jambi. Adapun tujuan penelitian ini adalah untuk mengetahui (1) Gambaran keputusan mahasiswa dalam memilih studi online di UPBJJ UT Jambi, dan (2) Faktor-faktor yang mempengaruhi keputusan mahasiswa dalam memilih studi online di UPBJJ UT Jambi. Penelitian ini termasuk jenis penelitian deskriptif dengan pendekatan kuantitatif. Adapun populasi penelitian ini adalah mahasiswa yang memilih studi online di UPBJJ UT Jambi, yang berjumlah 640 orang dengan teknik penarikan sampel pada penelitian ini adalah random sampling, sehingga diperoleh 87 orang mahasiswa sebagai sampel penelitian. Teknik pengumpulan data pada penelitian ini adalah angket. Sedangkan, teknik analisis data pada penelitian ini adalah analisis faktor dengan menggunakan program SPSS. Hasil penelitian menunjukkan bahwa (1) Variabel keputusan mahasiswa dalam memilih studi online berada pada kategori tinggi dengan rata-rata 4,29 dan Tingkat Capaian Responden (TCR) sebesar 85,81, (2) Terdapat 6 (enam) faktor dominan yang mempengaruhi keputusan mahasiswa dalam memilih studi online, yaitu (a) Faktor 1 yang diberi identitas Motivasi, yang terdiri dari item pernyataan F8, F9, F10, F11, dan F12, (b) Faktor 2 yang diberi identitas Kelompok Rujukan, yang terdiri dari item pernyataan F19, F20, dan F21, (c) Faktor 3 yang diberi identitas Kepercayaan dan Sikap, yang terdiri dari item pernyataan F4, F16, F17, dan F18, (d) Faktor 4 yang diberi identitas Keadaan Ekonomi, yang terdiri dari item pernyataan F3, F5, dan F6, (e) Faktor 5 yang diberi identitas Persepsi, yang terdiri dari item pernyataan F14, F15, dan F26, dan (f) Faktor 6 yang diberi identitas Peran dan Status, yang terdiri dari item pernyataan F23, F24, dan F25.
\end{abstract}

Kata Kunci: analisis; keputusan; studi online

Abstract. The purpose of this study was to determine (1) the description of student decisions in choosing online studies at UPBJJ UT Jambi, and (2) the factors that influence student decisions in choosing online studies at UPBJJ UT Jambi. The results showed that (1) the student's decision variable in choosing online studies was in the high category with an average of 4.29 and the Respondent Achievement Level (TCR) of 85.81, (2) There were 6 (six) dominant factors that influenced the decision. students in choosing online studies, namely (a) Factor 1 which is given the identity of the Motivation, which consists of statement items F8, F9, F10, F11, and F12, (b) Factor 2 which is given the identity of the Reference Group, which consists of statement items F19, F20, and F21, (c) Factor 3 which is given the identity of Belief and Attitude, which consists of statement items F4, F16, F17, and F18, (d) Factor 4 which is given the identity of Economic State, which consists of statement items F3, F5, and F6, (e) Factor 5 which is given the identity of Perception, which consists of statement items F14, F15, and F26, and (f) Factor 6 which is assigned the identity of Role and Status, which consists of statement items F23, F24, and F25.

Keyword: analysis; decision; online study

\section{PENDAHULUAN}

Unit Program Belajar Jarak Jauh Universitas Terbuka atau disingkat dengan UPBJJ UT merupakan lembaga pendidikan yang menyelenggarakan proses pembelajaran dengan sistem jarak jauh. Artinya, dalam proses pembelajaran, secara fisik mahasiswa dan dosen terpisah. Proses belajar seperti ini menuntut mahasiswa lebih proaktif, inisiatif, dan mampu belajar mandiri, yang mengacu pada sistem belajar "Student Centered Learning".

UPBJJ UT Jambi misalnya telah berupaya untuk memberikan layanan akademik yang baik serta menyediakan fasilitas pembelajaran dengan tujuan mahasiswa yang mendaftar di UT memperoleh kepuasan belajar serta menekan angka "Drop Out" menjadi lebih kecil. Untuk meningkatkan animo masyarakat, UPBJJ UT Jambi memulai peningkatan layanan melalui registrasi, bahan ajar, bantuan belajar, dan evaluasi hasil belajar. Peningkatan akademik ini menyangkut kualitas layanan administrasi maupun kualitas proses pembelajaran. Seiring dengan dinamika perkembangan teknologi informasi dan komunikasi, masyarakat telah diantarkan kepada era "Milenial".

Pesatnya kemajuan ICT ini berdampak besar terhadap perkembangan pendidikan belajar jarak jauh. Pesatnya perkembangan jaringan internet memberi peluang program belajar jarak jauh di desain sedemikian rupa hingga lebih interaktif dan komunikatif. Fenomena ICT ini sangat membantu UT dalam penyelenggaran belajar jarak jauh. Hal ini memicu UT untuk menyelenggarakan "Tutorial Elektronik". UPBJJ UT Jambi telah menyelenggarakan berbagai bantuan internet untuk layanan belajar. Layanan yang dimiliki UPBJJ UT Jambi adalah FasilitasUT Online (Tutorial Online), Tugas Akhir Program Online (TAP Online), Sistem Ujian Online (SUD), serta Buku Online. Hal ini diselenggarakan UPBJJ UT Jambi dengan orientasi menjawab tantangan kemajuan zaman dan memberikan 
layanan akademik yang memberikan kepuasan bagi mahasiswa, sehingga berdampak terhadap animo masyarakat kuliah di UT.

Berdasarkan data yang diperoleh jumlah mahasiswa baru Program Sarjana dan Diploma yang melaksanakan registrasi pada Tahun Akademik 2019.2 di UPBJJ UT Jambi adalah 640 orang. Yang terdiri dari 30 program studi pilihan baik Strat Dua (S2), Strata Satu (S1), Diploma. Dengan pilihan terbanyak pada program 118 / PGSD - S1 yakni sebanyak 117 mahasiswa, 311 / Ilmu Hukum S1 sebanyak 105 mahasiswa dan 54 / Manajemen-S1 sebanyak 89 mahasiswa.

Dengan informasi bahwa dewasa ini penyelenggaraan studi online ini telah diminati oleh masyarakat di Propinsi Jambi. Hal ini terlihat dari meningkatnya animo calon mahasiswayang registrasi di UPBJJ UT Jambi. Untuk itu penjajakan tentang faktorfaktor yang mempengaruhi keputusan mahasiswa dalam memilih studi online di UPBJJ UT Jambi perlu ditelusuri.

\section{Tinjauan Pustaka}

\section{Teori Modal Manusia (Human Capital)}

Becker (dalam Berliana, 2011:1) mengemukakan bahwa konsep utama dari human capital adalah bahwa manusia bukan sekedar sumber daya namun merupakan modal (capital) yang menghasilkan pengembalian (return) dan setiap pengeluaran yang dilakukan dalam rangka mengembangkan kualitas dan kuantitas modal tersebut merupakan kegiatan investasi".

Fattah (2009:16) mengemukakan bahwa pada dasarnya teori human capital adalah suatu aliran pengeluaran yang menganggap bahwa manusia merupakan suatu bentuk kapital sebagaimana bentukbentuk kapital lainnya". Human capital ini dapat diaplikasikan melalui berbagai bentuk investasi Sumber Daya Manusia (SDM) diantaranya pendidikan formal, pendidikan informal, pengalaman kerja, kesehatan, gizi serta transmigrasi.

Yahya (2009:205) mengemukakan bahwa "human capital adalah kekayaan yang menghasilkan investasi terhadap orang, khususnya pendidikan formal dan pelatihan". Konsep human capital mengungkapkan bahwa manusia memiliki keterampilan, kebiasaan dan pengetahuan yang dapat dijual ke majikan dalam bentuk gaji atau upah resmi dan dapat diharapkan menjadi aliran pendapatan selama masa hidup seseorang seperti physical capital. Hal ini didukung oleh pendapat Todaro (2006:438) yang menjelaskan bahwa sebagai barang normal, orang akan "membeli" lebih banyak modal manusia (human capital) jika pendapatannya naik.

Blaug (dalam Elfindri, 2001:20) menjelaskan bahwa teori modal manusia menyatakan bahwa lamanya masa pendidikan dan semakin lamanya akumulasi pengalaman berkorelasi positif dengan pendapatan". Individu yang memiliki pendidikan yang relatif lama memiliki pendapatan yang lebih tinggi apabila dibandingkan dengan individu yang tidak memiliki pendidikan formal. Hal ini senada dengan pendapat Simanjuntak (1998:70) yang menyatakan bahwa asumsi dasar teori human capital adalah bahwa seseorang dapat meningkatkan penghasilannya melalui peningkatan pendidikan". Dengan demikian bahwa dappat disimpulkan bahwa human capital merupakan seluruh keahlian, keterampilan, pengetahuan, dan kreativits manusia yang dapat meningkatkan nilai manusia.

\section{Prilaku Konsumen}

Perilaku konsumen merupakan tindakan-tindakan konsumen yang langsung melekat dalam proses mendapatkan, mengkonsumsi, dan menghabiskan produk atau jasa, termasuk proses yang mendahului tindakan ini. Perilaku konsumen ditimbulkan oleh adanya interaksi antara faktor-faktor lingkungan dan individu. Menurut Kotler dan Amstrong (dalam Ginting, 2011:34) pembelian konsumen sangat dipengaruhi oleh faktor-faktor yakni:

1. Faktor Pribadi antara lain umur dan tingkat daur hidup, kedudukan, keadaan ekonomi, gaya hidup, kepribadian dan konsep diri.

2. Faktor Psikologis perilaku konsumen juga dipengaruhi oleh faktor psikologis, seperti motivasi, persepsi, belajar, kepercayaan dan sikap

3. Faktor Sosial perilaku konsumen juga dipengaruhi oleh faktor sosial, seperti kelompok rujukan (reference group), keluarga, peran dan status.

4. Faktor Budaya memiliki pengaruh yang paling luas dan dalam kepada perilaku konsumen, seperti budaya, sub-budaya, dan kelas sosial.

\section{METODE}

Populasi penelitian ini sebesar 640 yakni mahaiswa mahasiswa baru Program Sarjana dan Diploma yang melaksanakan registrasi pada Tahun Akademik 2019.2 di UPBJJ UT Jambi, dimana jumlah sampel yang akan digunakan dalam pengumpulan data dengan menggunakan rumus Taro Yamane diperoleh sebesar 87. Dan teknik pengambilan sampel dilakukan dengan Proportional Random Sampling. Sedangkan, teknik yang digunakan dalam pengumpulan data penelitian ini adalah kuesioner, dengan menggunakan metode analisis faktor. Untuk mengukur hasil perolehan data yang didapat dari kuesioner sendiri, digunakan alat analisis, yakni SPSS.

\section{HASIL DAN PEMBAHASAN Analisis Deskriptif}

Analisis ini bertujuan untuk menggambarkan masing-masing variabel ke dalam tabel distribusi frekuensi, kemudian dilakukan analisis persentase serta memberikan interpretasi terhadap analisis tersebut. 
Mahyudin dan Yusrizal, Analisis Faktor-Faktor yang Mempengaruhi Keputusan Mahasiswa dalam Memilih Studi Online Program Sarjana dan Diploma di UPBJJ Ut Jambi

Tabel 1. Analisis Frekuensi Variabel Keputusan Mahasiswa dalam Memilih Studi Online

\begin{tabular}{cccc}
\hline $\begin{array}{c}\text { No Item } \\
\text { Pernyataan }\end{array}$ & $\begin{array}{c}\text { Rata-rata } \\
\text { Skor }\end{array}$ & TCR & Kategori \\
\hline 1. & 4.63 & 92.64 & Sangat Tinggi \\
2. & 4.48 & 89.66 & Tinggi \\
3. & 4.29 & 85.75 & Tinggi \\
4. & 3.93 & 78.62 & Cukup \\
5. & 3.99 & 79.77 & Cukup \\
6. & 4.60 & 91.95 & Sangat Tinggi \\
7. & 4.87 & 97.47 & Sangat Tinggi \\
8. & 3.85 & 77.01 & Cukup \\
9. & 4.08 & 81.61 & Tinggi \\
10. & 4.64 & 92.87 & Sangat Tinggi \\
11. & 3.90 & 77.93 & Cukup \\
12. & 3.98 & 79.54 & Cukup \\
13. & 4.51 & 90.11 & Sangat Tinggi \\
14. & 4.49 & 89.89 & Tinggi \\
15. & 3.91 & 78.16 & Cukup \\
16. & 4.77 & 95.40 & Sangat Tinggi \\
17. & 4.74 & 94.71 & Sangat Tinggi \\
18. & 4.78 & 95.63 & Sangat Tinggi \\
19. & 4.23 & 84.60 & Tinggi \\
20. & 3.66 & 73.10 & Cukup \\
21. & 4.03 & 80.69 & Tinggi \\
22. & 4.52 & 90.34 & Sangat Tinggi \\
23. & 4.07 & 81.38 & Tinggi \\
24. & 4.33 & 86.67 & Tinggi \\
25. & 4.05 & 80.92 & Tinggi \\
26. & 4.23 & 84.60 & Tinggi \\
Rata- rata & $\mathbf{4 , 2 9}$ & $\mathbf{8 5 , 8 1}$ & Tinggi \\
\hline
\end{tabular}

Dari hasil tersebut dapat dikatahui bahwa Ratarata Variabel Keputusan Mahasiswa Dalam Memilih Studi Online tergolong tinggi.

\section{Analisis Faktor \\ Faktor Motivasi}

Faktor yang terbentuk dari pernyataan-pernyataan pendukung dominan yang membentuk faktor 1 tergambar pada tabel sebagai berikut:

Tabel 2. Hasil Analisis Faktor 1

\begin{tabular}{ccc}
\hline No. & Kode & Koefisien Faktor \\
\hline 1. & F8 & 0,776 \\
2. & F9 & 0,796 \\
3. & F10 & 0,621 \\
4. & F11 & 0,844 \\
5. & F12 & 0,593 \\
\hline
\end{tabular}

Berdasarkan faktor 1 yang terbentuk terdiri dari 5 (lima) item pernyataan. Dimana, item pernyataan Keinginan untuk meningkatkan kemampuan diri mengarahkan Anda untuk memilih studi online di UPBJJ UT Jambi memiliki nilai koefisien faktor tertinggi, yaitu 0,844. Sedangkan, item pernyataan Keinginan diri untuk mampu mengikuti perkembangan ICT memotivasi Anda untuk memilih studi online di UPBJJ UT Jambi memiliki nilai koefisien faktor terendah, yaitu 0,593.

\section{Faktor Rujukan}

Faktor yang terbentuk dari pernyataan-pernyataan pendukung dominan yang membentuk faktor 2 tergambar pada tabel sebagai berikut:

Tabel 3. Hasil Analisis Faktor 2

\begin{tabular}{ccc}
\hline No. & Kode & Koefisien Faktor \\
\hline 1. & F19 & 0,668 \\
2. & F20 & 0,809 \\
3. & F21 & 0,698 \\
\hline
\end{tabular}

Berdasarkan tabel 3 di atas diketahui bahwa faktor 2 yang terbentuk terdiri dari 3 (tiga) item pernyataan. Dimana, item pernyataan Anda memilih studi online di UPBJJ UT Jambi karena memiliki rekan kerja yang mempunyai pilihan yang sama memiliki nilai koefisien faktor tertinggi, yaitu 0,809. Sedangkan, item pernyataan Anda memilih studi online di UPBJJ UT Jambi karena informasi yang diberikan oleh teman memiliki nilai koefisien faktor terendah, yaitu 0,668.

\section{Faktor Kepercayaan dan Sikap}

Faktor yang terbentuk dari pernyataan-pernyataan pendukung dominan yang membentuk faktor 3 tergambar pada tabel sebagai berikut:

Tabel 4. Hasil Analisis Faktor 3

\begin{tabular}{ccc}
\hline No. & Kode & Koefisien Faktor \\
\hline 1. & F4 & 0,599 \\
2. & F16 & 0,587 \\
3. & F17 & 0,658 \\
4. & F18 & 0,683 \\
\hline
\end{tabular}

Diketahui bahwa faktor 3 yang terbentuk terdiri dari 4 (empat) item pernyataan. Dimana, item pernyataan Anda meyakini bahwa UPBJJ UT Jambi memberikan pelayanan yang baik memiliki nilai koefisien faktor tertinggi, yaitu 0,683. Sedangkan, item pernyataan Anda memilih studi online di UPBJJ UT Jambi karena ingin merubah perilaku yang sesuai dengan tuntutan zaman memiliki nilai koefisien faktor terendah, yaitu 0,587 .

\section{Faktor Keadaan Ekonomi}

Faktor yang terbentuk dari pernyataan-pernyataan pendukung dominan yang membentuk faktor 3 tergambar pada tabel sebagai berikut:

Tabel 5. Hasil Analisis Faktor 4

\begin{tabular}{ccc}
\hline No. & Kode & Koefisien Faktor \\
\hline 1. & F3 & 0,596 \\
2. & F5 & 0,680 \\
3. & F6 & 0,694 \\
\hline
\end{tabular}

Diketahui bahwa faktor 4 yang terbentuk terdiri dari 3 (tiga) item pernyataan. Dimana, item pernyataan Anda memilih studi online di UPBJJ UT Jambi karena memperoleh bantuan dana beasiswa memiliki nilai koefisien faktor tertinggi, yaitu 0,694. Sedangkan, item 
pernyataan Anda memilih studi online di UPBJJ UT Jambi karena tuntutan pekerjaan memiliki nilai koefisien faktor terendah, yaitu 0,596.

\section{Faktor Persepsi}

Faktor yang terbentuk dari pernyataan-pernyataan pendukung dominan yang membentuk faktor 5 tergambar pada tabel sebagai berikut:

Tabel 6. Hasil Analisis Faktor 5

\begin{tabular}{ccc}
\hline No. & Kode & Koefisien Faktor \\
\hline 1. & F14 & 0,708 \\
2. & F15 & 0,460 \\
3. & F26 & 0,663 \\
\hline
\end{tabular}

Diketahui bahwa faktor 5 yang terbentuk terdiri dari 3 (tiga) item pernyataan. Dimana, item pernyataan Anda memilih studi online di UPBJJ UT Jambi karena faktor akreditasi memiliki nilai koefisien faktor tertinggi, yaitu 0,708. Sedangkan, item pernyataan Anda menganggap bahwa pilihan studi online di UPBJJ UT Jambi merupakan proses pembelajaran bergengsi memiliki nilai koefisien faktor terendah, yaitu 0,460.

\section{Faktor Peran Status}

Faktor yang terbentuk dari pernyataan-pernyataan pendukung dominan yang membentuk faktor 6 tergambar pada tabel sebagai berikut:

Tabel 6. Hasil Analisis Faktor 6

\begin{tabular}{ccc}
\hline No. & Kode & Koefisien Faktor \\
\hline 1. & F23 & 0,540 \\
2. & F24 & 0,427 \\
3. & F25 & 0,724 \\
\hline
\end{tabular}

Dimana, item pernyataan Peranan Anda dalam keluarga akan mempengaruhi keputusan Anda dalam memilih studi online di UPBJJ UT Jambi memiliki nilai koefisien faktor tertinggi, yaitu 0,724 . Selanjutnya, item pernyataan Alasan anda memilih studi online di UPBJJ UT Jambi agar dapat memfungsikan diri secara baik di tengah dunia kerja Anda memiliki nilai koefisien faktor terendah, yaitu 0,427 .

\section{SIMPULAN}

1. Variabel keputusan mahasiswa dalam memilih studi online berada pada kategori tinggi dengan rata-rata 4,29 dan Tingkat Capaian Responden (TCR) sebesar 85,81 .

2. Terdapat 6 (enam) faktor dominan yang mempengaruhi keputusan mahasiswa dalam memilih studi online, yaitu:

a. Faktor 1 yang diberi identitas Motivasi, yang terdiri dari item pernyataan F8, F9, F10, F11, dan F12. b. Faktor 2 yang diberi identitas Kelompok Rujukan, yang terdiri dari item pernyataan F19, F20, dan F21.

c. Faktor 3 yang diberi identitas Kepercayaan dan Sikap, yang terdiri dari item pernyataan F4, F16, F17, dan F18.

d. Faktor 4 yang diberi identitas Keadaan Ekonomi, yang terdiri dari item pernyataan F3, F5, dan F6.

e. Faktor 5 yang diberi identitas Persepsi, yang terdiri dari item pernyataan F14, F15, dan F26.

f. Faktor 6 yang diberi identitas Peran dan Status, yang terdiri dari item pernyataan F23, F24, dan F25.

\section{Saran}

Berdasarkan hasil penelitian yang peneliti peroleh, maka disarankan kepada:

1. Mahasiswa

Mahasiswa hendaknya memiliki motivasi dalam belajar, sehingga peningkatan hasil belajar dapat tercapai.

2. Universitas

Universitas hendaknya menciptakan layanan akademik yang kondusif, sehingga peningkatan kualitas proses pembelajaran dapat terwujud.

\section{DAFTAR PUSTAKA}

Berliana, Ruth. 2011. Human Capital: Manusia sebagai Modal Dasar atau Manusia sebagai Pemilik Modal Utama (Online) http://www.vibizmanagement.com diakses tanggal 18 Januari 2019.

Elfindri. 2001. Ekonomi Sumber Daya Manusia. Padang: Universitas Andalas.

Fattah, Nanang. 2009. Ekonomi dan Pembiayaan Pendidikan. Bandung: Remaja Rosda Karya.

Ginting, Nembah F. Hartimbul. 2011. Manajemen Pemasaran Cetakan Ke-1. Bandung: Yrama Widya.

Simanjuntak, Payaman. 1998. Pengantar Ekonomi Sumber Daya Manusia. Jakarta: Lembaga Penerbit Fakultas Ekonomi Universitas Indonesia.

Todaro. Michael P. 2006. Pembangunan Ekonomi Jilid 1 Edisi Kesembilan. Jakarta: Erlangga.

Yahya. 2009. Ekonomi dan Pembiayaan Pendidikan. Padang: Sukabina Offset. 